\title{
Cechy psychiczne człowieka a idee transhumanizmu ${ }^{1}$
}

Beata Płonka (Uniwersytet Jagielloński, Kraków)

\section{Wstęp}

Idee transhumanizmu wyrażają ludzkie pragnienie poprawiania własnej natury, które nie jest niczym nowym ani niezwykłym dla naszego gatunku. Nick Bostrom w swoim eseju Why I Want To Be a Posthuman When I Grow Up definiuje „po-człowieka” (posthuman) jako istotę posiadającą przynajmniej jedną ogólną zdolność (general central capacity) przekraczającą znacznie maksimum występujące naturalnie u jakiejkolwiek jednostki ludzkiej. Wśród ogólnych zdolności, na których skupia swoją uwagę, wyróżnia „zakres zdrowia” (healthspan), poznanie i emocje. Bostrom przytacza też fakty wskazujące na dość powszechne wśród ludzi pragnienie przedłużenia życia i zachowania zdrowia oraz udoskonalenia poznawczego i emocjonalnego. Zauważa też, że trudno jest precyzyjnie określić, na czym polega poprawa zdolności poznawczych, ze względu na ich złożoność i możliwe nakładanie się rozmaitych aspektów. Jeszcze trudniej jest zdefiniować ulepszanie zdolności emocjonalnych, choć większość z nas pragnie zredukować negatywne emocje i wzmacniać pozytywne, by móc rozwijać swoją osobowość i bardziej cieszyć się życiem. Bostrom przytacza też główne zastrzeżenia wysuwane w stosunku do „po-człowieka” (posthuman), czyli zachowanie tożsamości osobowej, zobowiązania (rodzinne i społeczne) oraz relacje interpersonalne i sposób życia. Argumentuje też, że możliwe jest, przy spełnieniu odpowiednich warunków, zachowanie przez jednostkę wszystkich wymienionych wartości, nawet po osiągnięciu poziomu „po-człowieka” (posthuman). Przytacza też liczne przykłady głębokich i radykalnych zmian, którym może podlegać człowiek w trakcie swojego życia, i które wpływają zarówno na jego tożsamość, jak i na relacje interpersonalne i sposób życia. Na zakończenie swoich rozważań Bostrom stwierdza, że bycie „po-człowiekiem” (posthuman) nie musi oznaczać, że nie pozostaje się nadal istotą ludzką, gdyż zależy to od rozumienia tego, co to znaczy być człowiekiem. Przy progresywnym tego rozumieniu „po-człowiek” (posthuman) może oznaczać jeden z możliwych sposobów bycia istotą ludzką2.

\footnotetext{
${ }^{1}$ Projekt został sfinansowany ze środków Narodowego Centrum Nauki przyznanych na podstawie decyzji numer DEC-2012/07/D/HS1/01099.

2 Por. Bostrom $(2013,49-50)$ : „It does not follow, at least not in any obvious way, that a posthuman could not also remain a human being. Whether or not this is so depends on what meaning we assign to the word "human". One might well take an expansive view
} 
Takie rozumienie wydaje się tym trafniejsze, że ludzie są istotami biologicznymi, stale przekraczającymi swoje granice. Poziom świadomości i zdolności poznawcze powodują jednak, że nasz gatunek gromadzi wiedzę i tworzy technologie umożliwiające wpływanie na własną biologię. Historia medycyny to najlepszy przykład ciągłej walki z naszymi biologicznymi ograniczeniami. Niezwykle trudno jednak wyznaczyć granicę między dopuszczalnym leczeniem a ulepszaniem człowieka, szczególnie jeśli spojrzymy na nasz gatunek $\mathrm{z}$ perspektywy ewolucyjnej. W naszych rozważaniach podejdziemy do problemu ulepszania człowieka (zwłaszcza cech psychicznych) od strony nauk biologicznych, ograniczymy sie jednak wyłącznie do zdolności poznawczych. To ograniczenie związane jest z rozległością i złożonością zagadnienia dotyczącego cech psychicznych człowieka. Nie ulega wątpliwości ogromne znaczenie innych aspektów ludzkiej psychiki, szczególnie emocji i zdolności związanych z podejmowaniem decyzji moralnych, jednak omówienie ich wymagałoby znacznie szerszego opracowania. Na początku wprowadzimy stosowane w biologii definicje różnych rodzajów cech, antropologiczną charakterystykę gatunku Homo sapiens za pomocą tzw. cech specyficznie ludzkich oraz ważne dla zrozumienia żywego organizmu rozróżnienie genotypu i fenotypu. Następnie zajmiemy się problematyką normy biologicznej i psychicznej oraz obecnym możliwościom ulepszania zdolności poznawczych człowieka. Na koniec przyjrzymy się praktycznym trudnościom, wynikającym ze złożoności zależności genotyp- fenotyp w organizmach żywych (polimorfizm, wpływ środowiska, efekty epigenetyczne) oraz związkom między genami i cechami psychicznymi (zwłaszcza zdolnościami poznawczymi).

\section{Cechy specyficznie ludzkie}

Dobitnym przykładem trudności, jakie sprawia nawet jednoznaczne morfologiczno-anatomiczne scharakteryzowanie człowieka są ciągle toczące się spory o Homo floresiensis ${ }^{3}$. W antropologii rozważano nawet problem, czy

of what it means to be human, in which case "posthuman" is to be understood as denoting a certain possible type of human mode of being if I am right, an exceedingly worthwhile type".

${ }^{3}$ W 2004 roku ogłoszono o odkryciu w jaskini Liang Bua na Flores niezwykłego szkieletu (LB1) sprzed ok. 18000 lat (pojemność czaszki 380-410 cm³, wzrost ok. 1m), który uznano za przedstawiciela nieznanego wcześniej gatunku Homo floresiensis, zwanego też hobbitem (Brown et al 2004). Odkrycie to zapoczątkowało serię kolejnych badań i trwającą do dziś dyskusję o przynależności gatunkowej spornych szczątków. Jedni badacze przytaczają argumenty za odmiennością gatunkową LB1 (Argue et al. 2006; Baab et al 2013; Kubo et al. 2013), inni natomiast przypisuja nietypowe cechy LB1 zespołom chorobowym (Jacob et al 2006), takim jak zespół 
„człowieczeństwo" oznacza posiadanie cech", które charakteryzują wyłącznie gatunek Homo sapiens (cechy specyficznie ludzkie), czy też wystarczy przynależność do rodzaju Homo a nawet rodziny Hominidae. Ostatecznie „zgodzono się, by za kryterium człowieczeństwa uznać przede wszystkim pewien szczególny typ zachowań, a mianowicie zachowania społeczne i to o takim natężeniu (czy komplikacji), by ich efektem była kultura" (por. Malinowski \& Strzałko 1985, 118). Zdolność do tworzenia kultury jest więc tak ważną cechą specyficznie ludzką, że $w$ badaniach procesu antropogenezy odgrywa ona kluczową rolę. Jest niezwykle interesujące, że spośród ogromnej liczby cech opisujących przedstawicieli naszego gatunku, antropologia odwołuje się do przejawów zachowań znacznie przekraczających sferę biologii. Wśród najważniejszych cech specyficznie ludzkich wymienia się wysoki poziom świadomości, samoświadomość i zdolność do myślenia abstrakcyjnego, które umożliwiają podejmowanie działań celowych (ze świadomością celu) oraz twórczych (artystycznych, poznawczych, tworzenia nowych narzędzi i technologii itp.). Cechami specyficznie ludzkimi są także potrzeba piękna i twórczej zabawy, jak również pragnienie poznania, wykraczające daleko poza zaspokojenie bezpośrednich życiowych potrzeb. Szczególną rolę odgrywa zdolność posługiwania się językiem, będąca podstawą przekazu pozagenetycznego, kluczowego dla funkcjonowania i rozwoju ludzkich społeczeństw. Cechą specyficznie ludzką jest też znaczne ograniczenie zachowań instynktownych, prowadzące do podporządkowania działań wymogom związanym z normami społeczno-kulturowymi, moralnymi lub religijnymi (niejednokrotnie będących w sprzeczności $\mathrm{z}$ naszą biologią lub „interesem gatunku”). Konsekwencją tego podporządkowania jest ludzka zdolność do zachowań czysto altruistycznych, odmiennych od zachowań „altruistycznych”, obserwowanych u niektórych zwierząt (tzw. „altruizm zwrotny", ukierunkowany na rekompensatę lub korzyść) (por. Kaczanowski 1998a oraz Malinowski \& Strzałko 1985, 150-167) ${ }^{5}$.

Larona (Hershkovitz et al 2007), zespół Majewskiego (karłowatość pierwotna typu II) lub zespół Downa (Eckhardt et al. 2014; Henneberg et al. 2014).

${ }^{4} \mathrm{~W}$ biologii cecha jest definiowana jako „1. właściwość danego obiektu lub procesu przyrody żywej dająca się rozpoznać, określić i analizować odpowiednimi metodami badawczymi. 2. Każda dająca się zaobserwować właściwość osobnika, dotycząca reakcji biochemicznych, procesów komórkowych, budowy anatomicznej, funkcjonowania narządów lub właściwości psychicznych" (por. Jura \& Krzanowska 1998, 94).

5 Cechy specyficznie ludzkie odróżniają człowieka od innych zwierząt, zwłaszcza naczelnych. Dzieli się je zwyczajowo na cechy morfofizjologiczne i psychiczne (lub cechy ekologiczne, anatomiczne, fizjologiczne i biologiczno-etologiczne). Cechy specyficznie ludzkie mogą występować jedynie u przedstawicieli Homo sapiens, lub też różnić się tylko stopniem nasilenia cechy w porównaniu z innymi gatunkami zwierząt. Wśród cech morfofizjologicznych wymienia się trzy zespoły cech-pionizacja ciała (w tym postawa wyprostowana i dwunożność), silny rozwój mózgu oraz wybiórcze odwłosienie skóry. 
Jest oczywiste, że przedstawiona tu krótka charakterystyka gatunku Homo sapiens, definiująca cechy specyficznie ludzkie $\mathrm{z}$ punktu widzenia antropologii, odnosi się do cech typowych, nie ujmuje jednak ogromnej różnorodności biologicznej przedstawicieli gatunku. Do tematu tego jeszcze wrócimy w związku z biologicznym rozumieniem normy, najpierw jednak musimy wprowadzić pojęcie genotypu i fenotypu.

\section{Genotyp i fenotyp}

Wprowadzono już biologiczne rozumienie cechy jako każdej możliwej do zaobserwowania właściwości organizmu oraz różne kategorie cech stosowane $\mathrm{w}$ antropologii. Wymienione tu cechy, takie jak cechy specyficznie ludzkie to $\mathrm{tw}$. cechy fenotypowe, które wykształcają się pod wpływem warunkujących je genów oraz czynników zewnętrznych. „Całokształt cech osobnika powstających w wyniku oddziaływania genotypu i czynników środowiska” tworzy jego fenotyp (por. Krzanowska 1998a, 247) ${ }^{6}$. Należy też podkreślić, że „fenotyp osobników tego samego genotypu może się znacznie różnić w zależności od środowiska, w jakim przebiegał ich rozwój ... . Ten zakres zmienności fenotypowej danego genotypu nosi nazwę normy reakcji. Genotyp zakreśla więc potencjalne możliwości wytworzenia różnych fenotypów w ramach swojej normy reakcji, natomiast realizacja tych możliwości zależy od konkretnego środowiska” (Krzanowska 1998a). Genotyp natomiast definiuje się jako „1. suma informacji genetycznej zawarta we wszystkich genach chromosomowych danego organizmu ... 2. układ alleli jednego lub kilku genów danego osobnika, np. genotyp homo- lub heterozygotyczny pod względem alleli danego genu" (por. Krzanowska 1998b, 398).

Wśród cech fenotypowych duże znaczenie ma podział na trzy kategorie: cechy dziedziczne, nabyte oraz wrodzone. Cechy dziedziczne są determinowane przede wszystkim przez czynniki genetyczne, natomiast przez cechy nabyte rozumie się cechy zmienione przez czynniki środowiskowe działające w trakcie rozwoju organizmu. Cecha wrodzona (kongenitalna) definiowana jest jako „właściwość organizmu uwarunkowana genetycznie, nie podlegająca zmianie w ciągu życia osobniczego" (por. Jura 1998, 97)7.

\footnotetext{
${ }^{6}$ Fenotyp może także oznaczać jedną konkretną cechę organizmu, taką jak barwa oczu.

7 Termin ten może być także używany w drugim znaczeniu, jako „właściwość odnosząca się do konstytucji morfologicznej, fizjologicznej lub psychicznej organizmu będąca odchyleniem od normy; jest zdeterminowana czynnikami genetycznymi lub środowiskowymi (np. urazem porodowym)" (Jura 1998). Warto zauważyć, że cechy wrodzone mogą być cechami dziedzicznymi (uwarunkowanymi genetycznie), lub powstałymi w okresie rozwoju embrionalnego pod wpływem czynników zewnętrznych (np. zakażenia niektórymi wirusami lub bakteriami, które prowadzą do pojawienia się nieprawidłowości rozwojowych).
} 
Gdy myślimy o ulepszaniu człowieka, musimy przede wszystkim określić jakie cechy chcemy ulepszać i w jakim stopniu. Jak już wspomniano, łatwo przekroczyć granicę między leczeniem a ulepszaniem, ze względu na ogromny zakres zmienności większości cech w ludzkiej populacji oraz specyficzny charakter stosowanego w biologii pojęcia normy.

\section{Norma biologiczna}

Duże zróżnicowanie pod względem genotypu w obrębie gatunku ludzkiego oraz odmienność warunków środowiska prowadzi do ogromnej różnorodności cech fenotypowych, zwiększonej jeszcze przez możliwość zachodzenia procesów chorobowych. Dlatego też niezwykle ważne w biologii jest pojęcie normy biologicznej (a w odniesieniu do człowieka także „normy psychicznej”). Jako normę biologiczną traktuje się taką wartość cechy ilościowej lub charakter cechy jakościowej ${ }^{8}$, która najczęściej występuje w populacji dla danego wieku (lub stadium rozwojowego). W naukach medycznych i antropologii normę dla cech metrycznych stanowi wartość średnia danej cechy razem z odchyleniem standardowym ${ }^{9}$. Przez normę dla cech niemetrycznych rozumie się te kategorie danej cechy, które najczęściej występują w populacji (wyrażone we frakcjach lub procentach). Norma biologiczna odnosi się więc do cech stanowiących średnią dla danej populacji, określa też zakres zmienności danej cechy charakteryzujący zdrowych przedstawicieli gatunku. Np. w większości populacji ludzkich średni wzrost wg. różnych autorów wynosi dla mężczyzn $163-174 \mathrm{~cm}$ oraz 153-163,5 cm dla kobiet. Inne normy wzrostu odnoszą się jednak do populacji karłowatych (pigmoidalnych) głównie australomelanezyjskich (Malezja, Sumatra, Jawa, Papua) i afrykańskich (średnia wzrostu to $137 \pm 4.36$ cm dla kobiet). Ważną cechą (odróżniającą człowieka współczesnego od innych

8 Cecha ilościowa (ciągła, poligeniczna) to „cecha wykazująca zmienność ciągłą, czyli taką, którą można przedstawić liczbowo na pewnej skali, np. wzrost, ciężar ciała ... . W wykształceniu c.i. bierze udział od kilku do kilkudziesięciu genów, zwanych poligenami, których drobne efekty kumulują się". Do cech ilościowych zalicza się cechy metryczne, czyli takie, których zmienność można określić za pomocą określonej miary. Cecha jakościowa (skokowa) to „cecha wykazująca zmienność skokową, czyli taką, którą można przedstawić za pomocą odrębnych, często przeciwstawnych kategorii, np. czerwona lub biała barwa kwiatu, prosty lub kędzierzawy włos. 0 sposobie wykształcenia c.j. decyduje jeden lub kilka genów o wyraźnych efektach" (por. Krzanowska 1998c, 1998d, 1998e).

9 Odchylenie standardowe S „można interpretować jako przeciętne zróżnicowanie wartości zmiennej losowej X wokół jej średniej." (Por. J. Greń 1987, 48). Zazwyczaj jako normę traktuje się wartość $\mathrm{x} \pm \mathrm{s}$ lub $\mathrm{x} \pm 1 / 2 \mathrm{~s}, \mathrm{w}$ zależności od charakteru danej cechy. Duże znaczenie w biologii mają też tzw. normy regionalne, czyli normy rozwojowe opisujące wartości różnych cech (np. wzrost lub masa ciała) charakterystyczne dla danej grupy wiekowej (uwzględniające różnice między populacjami oraz różnice płci); (por. Kaczanowski 1998b, 222). 
naczelnych) jest duża objętość mózgu, która wynosi średnio około $1500 \mathrm{~cm}^{3}$, ale za normę uznaje się objętość mieszczącą się $\mathrm{w}$ zakresie $750 \mathrm{~cm}^{3}-2400 \mathrm{~cm}^{3}$. Zakres zmienności objęty przez normę nie obejmuje jednak wszystkich możliwych wartości danej cechy, które mogą wystąpić u poszczególnych przedstawicieli gatunku (na ogół będących skutkiem rozmaitych zaburzeń prawidłowego rozwoju) ${ }^{10}$.

\section{Norma psychiczna i problem pomiaru}

Dużo trudniejsze jest określenie normy w odniesieniu do własności psychicznych człowieka, na który szczególny wpływ ma interpretacja zdrowia psychicznego. Dąbrowski jako zdrowie psychiczne określa „zdolność do rozwoju w kierunku wszechstronnego rozumienia, przeżywania, odkrywania i tworzenia coraz wyższej hierarchii rzeczywistości i wartości, aż do konkretnego ideału indywidualnego i społecznego" (Dąbrowski 1985, 29)11. Określenie normy bliższe wcześniej wprowadzonemu rozumieniu normy biologicznej może być stosowane w przypadku cech, które można zmierzyć za pomocą odpowiednio skonstruowanych testów. Do cech tych należy przede wszystkim ludzka zdolność określana zwykle mianem inteligencji. Inteligencja jest konstruktem teoretycznym, choć można ją także traktować jak stosunkowo trwałą cechę psychiczną, która przejawia się w zdolności do rozwiązywania nowych problemów. Do zachowań będących przejawem inteligencji zalicza się zdolności rozumienia, rozumowania, wnioskowania i myślenia abstrakcyjnego, zdolność uczenia się, zdolność kontrolowania własnego myślenia oraz zdolności adaptacyjne. Duża różnorodność sposobów rozumienia terminu „inteligencja” powoduje, że niektórzy autorzy unikają stosowania tego terminu, zastępując go pojęciem tzw. czynnika $g$. Powszechnie akceptowany dziś model psychometryczny zakłada, że zdolności poznawcze człowieka są zorganizowane hierarchicznie-od czynników specyficznych, takich jak zdolności werbalne, matematyczne, przestrzenne, pamięć oraz szybkość przetwarzania, do czynnika ogólnego (czynnika $g$ ). Czynnik $g$ jest jedną z najbardziej rzetelnych i najlepiej zdefiniowanych miar stosowanych w psychologii, którego stałość po okresie

\footnotetext{
${ }^{10} \mathrm{~Np}$. objętość mózgu $200-750 \mathrm{~cm}^{3}$ charakteryzuje osoby z mikrocefalią, zaburzeniem występującym w ponad 400 zespołach chorobowych o bardzo różnorodnym podłożu. $\mathrm{W}$ przypadku wzrostu najwyższy udokumentowany wzrost dorosłego człowieka to 272 cm, natomiast najniższy to ok. $57 \mathrm{~cm}$ (por. Malinowski \& Strzałko 1985, 63, 150-162; Hershkovitz et al. 2007; Berger et al. 2008; Brown et al. 2004; Jacob et al. 2006).

${ }^{11}$ Dąbrowski polemizuje też z rozumieniem zdrowia psychicznego jako braku zaburzeń psychicznych, stwierdzając: „wdług mojej opinii, zarówno wzmożona pobudliwość psychiczna, jak i większość nerwic i psychonerwic nie są chorobami, lecz są niezbędnym warunkiem wyraźnego, wszechstronnego rozwoju i stanowią one jeden $\mathrm{z}$ podstawowych warunków nie choroby psychicznej, a zdrowia psychicznego" (Dąbrowski 1985, 8).
} 
dzieciństwa jest najwyższa ze wszystkich badanych dotychczas cech behawioralnych (por. Rybakiewicz 2004, 57, 93-95; Plomin, DeFries, McClearn, \& McGuffin 2001, 178-180).

Największą trudność w pomiarze inteligencji stanowi skonstruowanie rzetelnych testów oraz ich odpowiednia standaryzacja. Przez wiele lat najbardziej popularnym testem pomiaru inteligencji był test Bineta (od 1916 roku tzw. wystandaryzowana Stanfordzka Skala Bineta). W. Stern zaproponował wskaźnik ilorazu inteligencji (I.I.), stanowiący iloraz wieku umysłowego oraz wieku życia pomnożony przez 100, zgodnie z którym wartość ilorazu między 70 i 79 jest linią graniczną między normą i upośledzeniem umysłowym, natomiast brak jest górnej granicy „normy umysłowej”. U osób dorosłych stosuje się tzw. dewiacyjny iloraz inteligencji, oparty na wartości średniej oraz odchyleniu standardowym (dla danej populacji), gdyż nie jest możliwe stosowanie „wieku umysłowego". Dewiacyjny I.I. zastosowany jest np. w opracowanej przez D. Wechslera w 1958 roku Skali Inteligencji dla Dorosłych Wechslera (WAIS) (por. Guilford 1978, 38-42; Tomaszewski 1979, 744-745; Wortman, Loftus, \& Marshall 1992, 422-430). Warto podkreślić, że poziom inteligencji mierzony za pomocą ilorazu inteligencji wykazuje $\mathrm{w}$ populacji ludzkiej tzw. rozkład normalny ${ }^{12}: 50 \%$ populacji charakteryzuje przeciętna inteligencja (90-109), 16.1\% powyżej (110-119) lub poniżej przeciętnej (80-89), u 6.7\% występuje inteligencja wysoka (120-129) lub na granicy normy (70-79), natomiast inteligencja bardzo wysoka (powyżej 130) lub opóźnienie umysłowe (poniżej 69) wykazuje $2.2 \%$ populacji. Badania wskazują, że zmienność wyników I.I. wynika w $52 \%$ z wpływów genetycznych, jest też silnie zależna od czynników środowiskowych i może się zmieniać w ciągu życia danej osoby (por. Rybakiewicz 2004, 93-104; Gläscher et al 2010; Plomin, DeFries, McClearn, \& McGuffin 2001, 178-180).

\section{Ulepszanie zdolności poznawczych}

Przedstawione tu skrótowo biologiczne rozumienie normy oraz cech genotypowych i fenotypowych wskazują na wspomniane wcześniej trudności w określeniu, na czym polega ulepszanie prowadzące od człowieka do „poczłowieka" (posthuman). We wspomnianym wcześniej eseju Why I Want To Be a Posthuman When I Grow Up Nick Bostrom zwraca uwagę na fakt, że ludzie są szczególnie chętni do ulepszenia swoich zdolności poznawczych. Pragnienie to jest wyraźnie widoczne w nakładach, jakie przeznaczamy na edukację, i to nie tylko $\mathrm{w}$ zdobywanie wiedzy, ale również rozwijanie różnych umiejętności

12 Rozkład normalny (rozkład Gaussa) jest najważniejszym (od strony teoretycznej i praktycznej) rozkładem ciagłej zmiennej losowej. Rozkład normalny zależy od dwóch parametrów - wartości oczekiwanej (średniej) i odchylenia standardowego zmiennej. Rozkład normalny jest symetryczny względem średniej (wykres, tzw. krzywa Gaussa, ma kształt kapelusza); por. Greń (1987, 82-83). 
(rozumowania, krytycznego myślenia, uczenia się, rozwiązywania problemów itd.). Bostrom zadaje tu ważne pytanie o zakres wprowadzanych ulepszeń, przyjmując perspektywę bliską ujęciu populacyjnemu. Zauważa on, że chęć poprawy zdolności poznawczych może dla każdego człowieka oznaczać jedynie stosunkowo niewielką zmianę, jednak bez osiągnięcia poziomu przewidywanego dla „po-człowieka” (posthuman). Z drugiej strony Bostrom poddaje pod rozwagę fakt, że ludzie o zdolnościach znacznie przekraczających przeciętną wykazują też większe pragnienie poprawy tych zdolności. Nie ma też podstaw do twierdzenia, że ulepszanie zdolności poznawczych do wartości maksymalnych w obecnej populacji (a także je przekraczających) byłoby pozbawione wewnętrznej wartości ${ }^{13}$. Pogląd ten wydaje się szczególnie trafny w świetle wprowadzonego wcześniej ujęcia normy biologicznej oraz faktu, że nie ma przyjętej górnej granicy normy w odniesieniu do poziomu inteligencji.

$\mathrm{Na}$ czym miałoby jednak polegać ulepszanie ludzkich zdolności poznawczych? Czy ma dotyczyć farmakologicznej stymulacji poszczególnych jednostek, czy chcemy trwale przekształcić cały gatunek? Do problemu zabawy w ewolucję jeszcze wrócimy, teraz zadamy tylko dwa ważne pytania. Czy gdyby taka „inżynieria gatunkowa”, będąca w istocie nowoczesną eugeniką, był możliwa, to radykalnie i sprawiedliwie dla poszczególnych osób zdecydowalibyśmy się na ujednolicenie poziomu zdolności, zaburzając ich rozkład normalny w ludzkiej populacji? Konsekwencją takiego postępowania byłoby jednak poważne zubożenie puli genowej i zmniejszenie różnorodności w obrębie gatunku, stanowiące trudne do przewidzenia ryzyko dla przyszłych pokoleń. A może dążylibyśmy jedynie do przesunięcia średniej populacyjnej stanowiącej normę, z zachowaniem naturalnej zmienności? Takie procesy obserwujemy $\mathrm{w}$ ludzkiej populacji np. w odniesieniu do ilorazu inteligencji. Badania wykazały wzrost średniego wyniku w standaryzowanych testach inteligencji o około 3 punkty $\mathrm{w}$ ciągu dekady. Zjawisko to nazywane jest efektem Flynna (Flynn effect) od nazwiska autora jego pierwszego systematycznego opracowania, obejmującego lata 1932-1978 (Flynn 1984). Są jednak wcześniejsze dane wskazujące, że wzrost ten trwa co najmniej od 1917 roku (Greiffenstein 2011). Obserwacje te zostały później potwierdzone dla różnych populacji, grup wiekowych i rodzajów stosowanych testów (Pietschnig et al. 2010; Trahan et al 2014). Kontrolowanie tego typu procesów w skali całej populacji ludzkiej jest przy obecnym stanie wiedzy niemożliwe, można natomiast wpływać na procesy poznawcze poszczególnych osób za pomocą

\footnotetext{
13 „It would be implausible to suppose that the current range of human capacity, in all domains, is such that while increment of capacity within this range are intrinsically rewarding, yet any further increases outside the current human range would lack intrinsic value. Again, we have a prima facie reason for concluding that enhancement of cognitive capacity to the highest current human level, and probably beyond that, perhaps up to and including the posthuman level, would be intrinsically desirable for the enhanced individuals." (Bostrom 2013, 36)
} 
środków farmakologicznych lub różnych technik stymulacji. Problemy etyczne związane z tymi technikami są obecnie szeroko dyskutowane, zwłaszcza w odniesieniu do problemu tożsamości (DeGrazia 2005; Erler 2011; Forlini et al. 2013; Johansson et al. 2014; Koivuniemi \& Otto 2014; Kraemer 2013; Liao \& Sandberg 2008; Mohamed \& Sahakian 2012; Shook et al. 2014; Wade et al. 2014), nie będziemy się jednak nimi zajmować. Poświęcimy natomiast nieco uwagi postępowi badań dotyczących sposobów manipulacji pamięcią.

\section{Ulepszanie pamięci}

W dobie ogromnego postępu w badaniach neurobiologicznych coraz częściej podejmuje się próby wspomagania funkcji mózgu, a zwłaszcza procesów pamięci, przy użyciu środków farmakologicznych lub rozmaitych technik. Uzyskano np. specyficzne wzmocnienie lub osłabienie określonych wspomnień w czasie fazy non-REM snu-przy tzw. „celowanej reaktywacji wspomnień” (targeted memory reactivation) (Antony et al. 2012; Diekelmann et al. 2011; Oudiette \& Paller 2013; Rasch et al 2007; Rolls et al. 2013; Rudoy et al 2009), przy zastosowaniu stymulacji przezczaszkowej (Marshall et al. 2006) oraz głębokiej stymulacji mózgu (Hamani et al. 2008; Laxton et al. 2010; Suthana et al. 2012). Obserwowano np. pozytywny wpływ donepezilu (lek badany w związku z chorobą Alzheimera) na pamięć epizodyczną (Repantis et al. 2010a), klonazepamu na pamięć deklaratywną (Rodriguez et al. 2013). Dobrze znany jest wpływ metylfenidatu na pamięć oraz modafinilu na pamięć operacyjną i uwagę, jednak środki te mają też wiele skutków ubocznych (Kumar 2008; Müller et al. 2013; Repantis et al. 2010b). Badania wskazują też na przyszłe możliwości selektywnego wymazywania wspomnień, głównie wywołujących strach (Han et al 2009), przy użyciu np. kanabinoidów i glukortykoidów (deBitencourt et al. 2013; Rabinak et al. 2013). Pewne sukcesy w wymazywaniu traumatycznych wspomnień uzyskano dzięki zastosowaniu tzw. beta-blokerów (Kindt et al. 2014). Stwierdzono np. osłabienie intensywności wspomnień i zmniejszenie prawdopodobieństwa wystąpienia zespołu stresu pourazowego (PTSD) w przypadku stosowania inhibitorów deacetylazy histonowej (Kuriyama et al 2013) oraz propranololu krótko po zajściu traumatycznego zdarzenia, także w badaniach klinicznych (Brunet et al. 2008; Cahill et al. 1994; Poundja et al. 2012). Badano także wpływ propranololu na wspomnienia związane $\mathrm{z}$ uzależnieniem od narkotyków i zaobserwowano pewne zmniejszenie głodu narkotykowego, efekt nie był jednak trwały (Saladin et al. 2013). Należy jednak dodać, że w niektórych przypadkach nie uzyskano zmniejszenia skutów PTSD przez propranolol (Wood et al. 2015), badania wskazują też na duże znaczenie różnic genetycznych np. dla powodzenia terapii (Agren et al. 2012; Andersson et al. 2013). Możliwe wydaje się nawet wywoływanie fałszywych wspomnień (false memories) w związku z faktem, że ludzkie wspomnienia (zwłaszcza autobiograficzne) nie stanowią wiernej kopii 
przeszłych zdarzeń ${ }^{14}$. W przeprowadzonych dotychczas badaniach wykazano np. możliwość sztucznego wytworzenia połączenia między wspomnieniami wcześniejszych zdarzeń (Arzi et al. 2012; Ramirez et al 2013).

\section{Złożoność zależności genotyp-fenotyp u organizmów żywych}

Niezwykle szybki rozwój nauk biologicznych oraz nowych technologii, jaki obserwujemy $\mathrm{w}$ ostatnich latach, prowadzi do bardzo ambitnych wizji radykalnego ulepszenia człowieka - fizycznego i psychicznego, a nawet uzyskania przez niego nieśmiertelności. Szczególnie śmiałe wizje transhumanizmu wyraźnie ignorują trudności i niebezpieczeństwa związane z ich realizacją. Rzeczywistość biologiczna jest wszakże znacznie bardziej złożona i przekonanie o możliwości uzyskania skomplikowanycyh efektów za pomocą prostych środków jest nieporozumieniem. Należy pamiętać, że organizmy żywe to obiekty wyjątkowo złożone, co pociąga za sobą konieczność wykreowania specyficznego podejścia, stosowanego do opisu układów nierównowagowych, dynamicznych i nieliniowych, a przy tym konieczność uwzględnienia aspektów badanych przez teorię informacji i cybernetykę. Nawet pobieżna charakterystyka powyższych aspektów jest niemożliwa w ramach naszych obecnych rozważań, skupimy się więc jedynie na dwóch zagadnieniach związanych z dynamiką układów żywych.

Bardzo ważny jest fakt, że organizm cechuje ścisłe powiązanie między strukturą i funkcją (obustronna zależność). Struktura stanowi podłoże procesów życiowych, jednak struktura specyficznie rozumiana. Pojawiło się pojęcie „dynamiki strukturalnej”, najbardziej odpowiednie do opisu tego typu struktur. Jak zauważa Władysław J. H. Kunicki-Goldfinger „życie możemy uważać za proces, ale żywy organizm musimy uważać za strukturę, realizowaną w procesie życia i będącą podłożem tego procesu ... Życie ... odznacza się też tym, że składa się z wielu poziomów hierarchicznych. To co żywe jest więc hierarchicznie ukształtowaną strukturą" (Kunicki-Goldfinger 1978, 35). To klasyczne rozumienie obustronnej zależności między strukturą i funkcją wyraża się np. w tym, że funkcja makrocząsteczki jest pochodną jej struktury

14 Niezwykle interesujący przykład stanowią ludzie o wybitnej pamięci autobiograficznej (highly superior autobiographical memory HSAM), których zdolność wydobywania z pamięci szczegółów przeszłych zdarzeń wielokrotnie przewyższa średnią. Stwierdzono np., że średni wynik dla grupy HSAM stanowi 25.5 SD (odchylenia standardowego) powyżej średniego wyniku dla grupy kontrolnej w teście 10 Date Quiz. Osoby takie nie wykazują jednak mniejszej skłonności do tworzenia fałszywych wspomnień (por. Patihis et al. 2013). Weryfikacja szczegółów wspomnień wykazała ich trafność w 97\%. Stwierdzono ponadto, że u osób o wybitnej pamięci autobiograficznej występują różnice morfologiczne $\mathrm{w}$ obszarach mózgu związanych z tym rodzajem pamięci - głównie bruzda skroniowa (por. LePort et al. 2012). 
(pierwszo-, drugo- i trzeciorzędowej), jednocześnie jednak struktura ta zależna jest od funkcji innych makromolekuł, realizujących informację zapisaną $w$ materiale genetycznym (DNA). Przebieg tych procesów może być zakłócony nawet przez pozornie nieznaczące zmiany w otoczeniu lub programie genetycznym, o czym wspomnimy nieco później. Klasyczne rozumienie zależności między strukturą i funkcją traktowane było jak rodzaj dogmatu, od którego jednak pojawiają się coraz liczniejsze wyjątki. Wiadomo obecnie, że istnieje wiele białek, które nie mają jednoznacznie określonej struktury trzeciorzędowej, pełnią jednak ważne funkcje w regulacji ekspresji informacji genetycznej (np. w układzie nerwowym). Szczególnie znane przykłady to białko Yin Yang 1 (He \& Casaccia-Bonnefil 2008) oraz amyloid, związany z etiologią choroby Alzheimera (Nicolas \& Hassan 2014). Struktura ta ma więc charakter dynamiczny (układ otwarty termodynamicznie, wymieniający materię i energię $z$ otoczeniem). Powstaje ona i podlega procesom wzrostu i rozwoju w wyniku realizacji instrukcji zawartych $\mathrm{w}$ genomie $\mathrm{w}$ formie sekwencji nukleotydów w DNA (por. Styrna 1998). Wspomniano już wcześniej, że informacja zawarta w genach danego organizmu (genotyp) przekłada się na jego fenotyp. Należy tu podkreślić, że $w$ genomie zawarta jest zarówno informacja o strukturze pierwszorzędowej makromolekuł RNA (i za ich pośrednictwem białka, a co za ty idzie, organelli, komórek, tkanek i organów), jak i program realizacji tej informacji „strukturalnej” w trakcie życia organizmu. Dla pełnego poznania zależności między genotypem i fenotypem danego indywiduum jest więc konieczne, oprócz opisu sekwencji jego DNA oraz identyfikacji genów, także określenie porządku, w jakim zachodzą procesy ekspresji tych genów. Nie zapominajmy także, że procesy te zachodzą w interakcji ze środowiskiem i są silnie od niego zależne, co dopełnia ogromną złożoność zależności genotyp-fenotyp. Trudno przecenić znaczenie, jakie dla nauki ma określenie sekwencji ok. 3 miliardów par nukleotydów w ludzkim DNA oraz identyfikacja ok. 25 tysięcy zawartych tam genów (Human Genome Project). Jest to jednak dopiero początek drogi wiodącej do zadowalającego opisu zależności między konkretnymi genami i odpowiednimi cechami fenotypowymi ${ }^{15}$. Zaskakująco niska liczba genów zwróciła uwagę na stanowiące większość genomu człowieka tzw. „niekodujące” DNA, któremu

$15 \mathrm{Na}$ stronie http://www.ncbi.nlm.nih.gov/projects/mapview/map_search. cgi?taxid=9606 dostępna jest mapa genów rozmieszczonych na wszystkich chromosomach człowieka. Z powodu niewystarczającej liczby danych nie można jeszcze opisać programu realizacji informacji genetycznej niezbędnego do stworzenia struktur ludzkiego organizmu na wszystkich poziomach jego organizacji. Warto dodać, że udało się już sformułować taki program dla procesów embriogenezy muszki owocowej (por. Bodnar 1997; Bodnar \& Bradley 2001). 
obecnie przypisuje się decydującą rolę w regulacji procesów ekspresji genów struktury ${ }^{16 .}$

\section{Polimorfizm}

Dla lepszego zrozumienia trudności, z którymi musimy się zmierzyć, jeśli chcemy poważnie myśleć o ulepszaniu cech fenotypowych człowieka (w szczególności cech psychicznych i w odniesieniu do całej populacji), musimy jeszcze poruszyć problem polimorfizmu. Polimorfizm oznacza występowanie w populacji wielu wersji (wariantów) danego genu i jest skutkiem zachodzenia w materiale genetycznym różnych mutacji. Mutacje zachodzące w genach struktury (kodujących białka) niekiedy tylko wpływają znacząco na funkcje tych białek (Arodź \& Płonka 2012; 2013), powodując duże zmiany w ich strukturze lub ekspresji (jej wzrost, spadek albo zahamowanie) i czasem prowadząc do różnych zespołów chorobowych ${ }^{17}$. Paradoksalnie, niejednokrotnie jedynie odkrycie związku między pewną mutacją danego genu a określoną chorobą pozwala na poznanie funkcji tego genu w organizmie (związku gen-cecha

16 Próbą ujęcia tego związku od strony teorii informacji jest oparta o prace J. von Neumanna i H. Pattee koncepcja wyróżniająca dwa komplementarne aspekty samoreprodukujących się systemów - rządzony przez prawa fizyki aspekt materialny/energetyczny oraz aspekt znakowy, kierowany przez zasady ewolucji (von Neumann-Pattee principle of matter-sign complementarity). Ji (1999) twierdzi, że komórkę można traktować jako molekularną maszynę, która akceptuje komórkowy język zakodowany w DNA. W oryginale: „can be viewed as a molecular machine that accepts cell language encoded in DNA, just as the Turing machine acts as an abstract machine that accepts and defines a formal language encoded on a tape. It is to be noted that these molecular entities that drive the cell, namely conformons and IDS's, can be viewed as the microscopic embodiments of the matter-symbol complementarity discussed by Pattee."

17 Badania DNA różnych ludzi wykazały $\mathrm{w}$ przypadku substytucji pojedynczych nukleotydów zmienność międzyosobniczą średnio w 3.3 miliona nukleotydów w całym genomie (ok. 1 nukleotyd na 1000), natomiast w przypadku delecji (wypadnięcie) i insercji (wstawienie) większych fragmentów DNA zmienność do 15 milionów nukleotydów. Przyjmuje się ( $\mathrm{w}$ pewnym uproszczeniu), że stopień różnorodności genetycznej populacji jest zależny od jej wielkości oraz od szybkości mutacji (mutation rate), natomiat średnia częstość substytucji (podstawienia) jednego nukleotydu w genomie wynosi $10^{-8}$ na nukleotyd na pokolenie. Poszczególne warianty genu różnią się częstością występowania w populacji, wynikającą głównie z presji selekcyjnej, która z kolei zależna jest od efektu fenotypowego tych wariantów. Działanie doboru dotyczy głównie wariantów genu wpływających na prawdopodobieństwo przeżycia jednostki, wpływa jednak pośrednio również na częstość dziedziczonych z nim wspólnie wariantów innych genów (linked variants). Różne geny wykazują różną częstość mutacji zmieniających ich produkt. Niektóre geny wykazują bardzo niską częstość mutacji (np. geny histonów), dla innych natomiast obserwuje się duży polimorfizm (np. fibrynogen) (por. Harris \& Meyer 2006; Kingsley 2009; Strachan \& Read 1999). 
fenotypowa). Wspomniano już, że niemożliwe jest przewidzenie genetycznego podłoża danej cechy i w każdym przypadku musi być ono stwierdzone eksperymentalnie. Co więcej, nawet w przypadku podobnych cech ich różne warianty mogą mieć odmienne podłoże (np. mutacje w genie „struktury” kodującym białko, mutacje w rejonie regulatorowym genu „struktury”, różna liczba kopii genu „struktury”). Zdarza się również, że dany gen może wpływać na wiele cech fenotypowych, regulując aktywność odpowiednich genów, jak białka szoku cieplnego lub wspomniany już gen Yin Yang 1 (He \& CasacciaBonnefil 2008; Kingsley 2009; Nicolas \& Hassan 2014).

Poglądy na przebieg procesów ekspresji genów (prowadzących do powstania cech fenotypowych) uległy w ostatnich dziesięcioleciach znacznej zmianie, wraz z odkryciem wpływów epigenetycznych oraz możliwej roli tzw. mutacji synonimicznych. Od dawna było wiadomo, że różne mutacje $\mathrm{w}$ odmienny sposób wpływają na strukturę i funkcję białka kodowanego przez dany gen-szczególne znaczenie mają tu mutacje zmieniające sekwencję aminokwasów tego białka w wyniku zmian w kodonie. W ostatnich latach stwierdzono jednak, że nawet uważane wcześniej za obojętne mutacje synonimiczne (silent mutations) wpływają na ekspresję danego genu, mogą też zmieniać drugo- i trzeciorzędową strukturę białka. Mutacje te wywołują spadek efektywności translacji, co może prowadzić do zmian konformacji białka lub jego poziomu w komórce, a co za tym idzie, do zmian fenotypowych (Chamary et al. 2006; Dana \& Tuller 2014; Fung \& Gottesman 2009; Kudla et al. 2009; Tsai et al. 2008).

\section{Efekty epigenetyczne}

Efekty epigenetyczne związane są z modyfikacjami chromatyny, które zachodzą bez zmiany sekwencji DNA, prowadzą jednak do zmian w aktywności genów (np. metylacja promotora danego genu prowadzi do jego wyłączenia). Najwcześniej poznane mechanizmy epigenetycznej regulacji ekspresji genów polegają na przeprowadzanej przez metylotransferazy metylacji DNA (powoduje zahamowanie transkrypcji) oraz post-translacyjnych modyfikacjach histonów (głównie ich metylacji lub acetylacji). Acetylacja histonów jest kontrolowana przez odpowienie acetylotransferazy i prowadzi do zwiększenia efektywności transkrypcji, natomiast ich deacetylacja (przez deacetylazy) związana jest z zahamowaniem transkrypcji. Te złożone procesy, w które zaangażowane jest też wiele innych czynników (np. inhibitory enzymów), kontrolują porządek czasowy i poziom ekspresji genów, zwiększając różnorodność możliwych fenotypów przy danym genotypie (Fagiolini et al. 2009).

Populację ludzką charakteryzuje więc duże zróżnicowanie genotypowe (polimorfizm) i jeszcze większa różnorodność pod względem fenotypu, dotycząca nawet jednostek identycznych genetycznie (bliźnięta monozygotyczne). Stwierdzono, że genomy bliźniąt monozygotycznych są 
nierozróżnialne $\mathrm{w}$ początkowych latach życia, jednak liczba różnic epigenetycznych rośnie z wiekiem i różnicami w trybie życia (Fraga et al. 2005). Wydaje się, że wpływ środowiska na różnorodność fenotypową w populacji ludzkiej jest szczególnie duży w przypadku cech psychicznych, gdyż związki między genotypem i fenotypem są w tym przypadku bardzo skomplikowane. Uważa się obecnie, że większość ludzkich zachowań i cech psychicznych jest uwarunkowana wielogenowo, w populacji występuje więc rozkład normalny tych cech. Zaburzenia zachowania i choroby psychiczne są natomiast na ogół przypisywane działaniu pojedynczych genów. Różnice indywidualne w ludzkiej populacji wyrażają się w różnicach ilościowych poziomu (natężenia) danej cechy psychicznej lub zachowania u poszczególnych osób18.

W ostatnich latach stwierdzono ogromną złożoność mechanizmów epigenetycznych działających w mózgu (Qureshi \& Mehler 2014), m.in. udział w procesach rozwoju mózgu i powstawaniu chorób neurologicznych (Roberts et al. 2014; Shen et al. 2014), różnicowaniu neuronów (Imamura et al. 2014), mechanizmach plastyczności mózgu (Aksoy-Aksel et al. 2014; Fass et al 2013), procesach uczenia się oraz tworzeniu i modyfikacji śladów pamięciowych (Cortes-Mendoza et al. 2013; Jarome et al 2014), w tym wspomnień wywołujących lęk (Gupta-Agarwal et al 2014), powstawaniu emocji (Covington et al. 2009). Wykazano także zmiany epigenetyczne w różnych obszarach mózgu (prowadzące do różnych zachowań) m.in. pod wpływem stresu, interakcji społecznych oraz matczynej opieki we wczesnej fazie życia (Griffiths \& Hunter 2014; Kaverne \& Curley 2008; Szyf et al. 2007). Postuluje się także, że mechanizmy epigenetyczne leżą u podłoża wspomnianego już wcześniej wzrostu średniego ilorazu inteligencji w ludzkiej populacji (Greiffenstein 2011).

Należy podkreślić, że zakres wpływów epigenetycznych na zmienność cech psychicznych i zachowań ludzi jest niemożliwy do określenia, gdyż nowe badania stale prowadzą do odkrywania nieznanych (lub niedocenianych) wcześniej mechanizmów np. procesów transkrypcji prowadzących do

18 Wpływem czynników genetycznych i środowiskowych na zmienność cech psychicznych i zachowań w ludzkiej populacji zajmuje się genetyka zachowania (genetyka behawioralna). Wśród czynników genetycznych wyróżnia się tzw. czynniki addytywne (wyrażają się w sumowaniu działania wielu genów w powstaniu danej cechy) i nieaddytywne. Czynniki nieaddytywne są związane z odziaływaniami między genami, które zmniejszają podobieństwo w zakresie danej cechy między rodzicami i dziećmi oraz między rodzeństwem (wyjątek stanowią bliźnięta monozygotyczne, dla których te czynniki są wspólne). Wpływ środowiska na zmienność cech psychicznych i zachowania wyraża tzw. środowisko wspólne (ogół czynników określających warunki życia danej rodziny, upodabniających do siebie jej członków) oraz środowisko specyficzne (ogół indywidualnych doświadczeń danej jednostki, różnicujące osoby) (por. Rybakiewicz 2004, 45-52; Oniszczenko, \& Dragan 2008, 10-14). 
powstania różnych rodzajów ncRNA (tzw. niekodujące RNA) ${ }^{19}$. Stale rośnie też liczba danych wskazujących na ogromne znaczenie ncRNA dla funkcjonowania mózgu. Szczególnie dużo uwagi poświęca się obecnie prawie całkowicie nieznanym procesom kontroli epigenetycznej aktywności ruchomych elementów genetycznych, RNA (RNA epigenetics) oraz genów mitochondrialnych (Qureshi \& Mehler 2014).

\section{Geny i cechy psychiczne}

Wszystkie przedstawione tu fakty wskazują wyraźnie na ogromy stopień złożoności procesów prowadzących do pojawienia się cech psychicznych. Bardzo trafnie ujęli to Y. Levy i R. P. Ebstein, zwracając uwagę na wiele uproszczeń i nieporozumień występujących przy ujęciu związków między genami i ludzką psychiką (zwłaszcza zdolnościami poznawczymi). Bardzo często używa się swego rodzaju „etykietek” (np. „geny intelektu” (smart genes), "geny języka” lub „geny agresji”), co sugeruje \& Ebstein 2009) ${ }^{20}$.

Szczególnie dobitnym przykładem takiego podejścia jest gen FOXP2, który krótko po jego odkryciu został okrzyknięty "genem języka”, lub wręcz „genem człowieczeństwa”. Nie ulega wprawdzie wątpliwości, że produkt genu FOXP2 (czynnik transkrypcyjny (forkhead box P2), Foxp2), jest niezbędny w trakcie embriogenezy do prawidłowego rozwoju ośrodków językowych oraz neuronalnych połączeń niezbędnych $\mathrm{w}$ procesie mówienia. Stwierdzono, że pewne mutacje tego genu prowadzą do zaburzeń mowy zwanych dyspraksją werbalną (SPCH1; speech-language disorder 1), charakteryzujących się nieprawidłowościami w funkcjonowaniu stref motorycznych w korze czołowej (m.in. niższą aktywnością obszaru Broki). Wykazano ponadto związek aktywności FOXP2 $\mathrm{z}$ inną, bardziej powszechną $\mathrm{w}$ populacji, formą

19 Odkrycie różnych rodzajów ncRNA, które pełnią w komórce rozmaite kluczowe funkcje podważyło tzw. „centralny dogmat biologii molekularnej” (przepływ informacji DNA $\rightarrow$ RNA $\rightarrow$ białko) oraz doprowadziło do redefinicji genu (dla uwzględnienia także odcinków DNA kodujących ncRNA, oprócz „klasycznych” genów, których transkrypty podlegają translacji na białka). Warto zaznaczyć, że w DNA człowieka znajduje się tysiące razy więcej genów ncRNA, niż genów kodujących białka. Uważa się także, że geny te odegrały ogromną rolę w ewolucji ludzkiego mózgu (Gerstein et al. 2007; Qureshi \& Mehler 2014).

20 "there have been quite a few articles in which a plea has been made to behavioral scientists to revise their misconceptions about gene-behavior correlates if they hope to 'untangle the webs that link genes to cognition' (Fisher 2006, 270). A frequent misunderstanding concerns talk about 'smart genes', 'language genes' or 'aggressive genes'. Such talk implies direct pathways from genes to complex behaviors, whereas biology tells us that those routes are multifaceted and nonlinear (Marcus \& Fisher 2003). Furthermore, such discourse neglects the role played by the intricate sets of ontogenetic factors, environments, developmental timing and stochastic events on the behavioral outcome" (Rutter, Moffitt, \& Caspi 2006; por. też Levy \& Ebstein 2009, 657). 
upośledzenia mowy (SLI, specific language impairment). Związek ten jest pośredni i wynika z wpływu Foxp2 na ekspresję genu CNTNAP2, kodującego neureksynę, pośredniczącą w oddziaływaniach między neuronami i komórkami glejowymi w trakcie rozwoju układu nerwowego. Nazwanie genu FOXP2 genem języka jest jednak ogromnym uproszczeniem, gdyż zdolności językowe wykazują korelację $\mathrm{z}$ wieloma różnymi genami, m.in. ATP2C2 (calciumtransporting ATPase, type 2C, member 2), DYX1C1(dyslexia susceptibility 1 candidate 1), KIAA0319, DCDC2 (doublecortin domain containing 2) i ROBO1 (roundabout, axon guidance receptor, homolog 1 (Drosophila)), prawdopodobny też jest wpływ genów MRPL19 (mitochondrial ribosomal protein L19) i C2ORF3 (GC-rich sequence DNA-binding factor 2; oficjalny symbol GCFC2) (Anthoni et al. 2007; Newbury et al. 2009; Paracchini 2011; Scerri et al. 2011). Uważa się, że białka kodowane przez geny DYX1C1, KIAA0319, DCDC2 i ROBO1 biorą udział w procesach migracji neuronów w rozwijającym się mózgu, co tłumaczy wpływ tych genów na zdolności językowe. Stwierdzono też, że rozmaite zaburzenia funkcji genów DYX1C1, KIAA0319 i DCDC2 prowadzą do deficytów zdolności czytania lub różnych typów dysleksji. Dwa pozostałe geny, dla których w badaniach populacyjnych wykazano korelację ze zdolnościami językowymi to geny MRPL19 (produkt ważny dla syntezy białek w mitochondriach) oraz C2ORF3, kodujący czynnik, który według ostatnich doniesień może być zaangażowany w procesy obróbki rRNA w komórkach (Yoshimoto et al. 2014). Ponadto, kodowany przez FOXP2 czynnik transkrypcyjny Foxp2 pobudza lub hamuje ekspresję ok. 300 genów w komórkach mózgu, a najsilniejszy wpływ stwierdzono w przypadku 34 genów. Gen FOXP2 oddziałuje więc na wiele procesów zachodzących w rozwijającym się mózgu, takich jak neurotransmisja, różnicowanie neuronów, naprowadzanie aksonów (axon guidance) oraz plastyczność synaps i może mieć związek z licznymi zachowaniami i zdolnościami człowieka (Devanna et al. 2014; Fisher \& Scharff 2009; Fisher et al. 1998; Liegeois et al. 2003; Marcus \& Fisher 2003; Spiteri et al. 2007; Vernes et al. 2008). Stwierdzono np. wpływ Foxp2 na ekspresję genu receptora czynnika wzrostu hepatocytów MET (proto-oncogene, receptor tyrosine kinase), jednego z genów ryzyka ASD (autism spectrum disorder) (Mukamel et al. 2011). Wykazano także, że ekspresja samego genu FOXP2 jest regulowana przez co najmniej trzy rodzaje miRNA, może być więc zależna od różnych czynników środowiskowych (Fu et al. 2014). Kilka lat później mianem „genu człowieczeństwa" prasa popularna obdarzyła inny gen: miR-941, specyficzny dla ludzi, ulegający znacznej ekspresji w mózgu i prawdopodobnie regulujący funkcję genów zaangażowanych w działanie neuroprzekaźników (Hu et al. 2012).

Wśród tendencji transhumanizmu wzmacnianie zdolności poznawczych (cognitive enhancement) zajmuje szczególne miejsce, ze względu na ogromną wagę, jaką do nich przywiązujemy. Wciąż jest jednak bardzo daleko do poznania genetycznego podłoża tych zdolności, pomimo iż na temat zaburzeń 
poznawczych wiemy więcej, niż o podstawach jakichkolwiek innych ludzkich cech psychicznych. Opisano ponad 100 genetycznych zaburzeń, charakteryzujących się wśród ich symptomów upośledzeniem umysłowym (m.in. spowodowane przez aberracje chromosomowe zespoły: Downa, Angelmana, Prader-Williego i Williamsa oraz zespół łamliwego chromosomu $\mathrm{X}$ ). Wedle jednej z hipotez (general genes hypothesis) wiele genów, których mutacje wywołują upośledzenie umysłowe, związane jest $\mathrm{z}$ ogólnymi zdolnościami poznawczymi, m.in. geny kodujące enzymy zaangażowane $\mathrm{w}$ ważne procesy metaboliczne w komórkach, takie jak APOE (apolipoproteiny E), CBS (beta syntazy cystationiny) i SSADH (dehydrogenazy semialdehydu bursztynowego; oficjalny symbol ALDH5A1). Stwierdzono także, że na ogólne zdolności poznawcze wpływają prawdopodobnie także geny zaangażowane $\mathrm{w}$ procesy neurotransmisji, takie jak DRD2 (gen receptora dopaminowego D2), COMT (katecholo-O-metylotransferazy), BDNF (neurotrofowego czynnika pochodzenia mózgowego), CHRM2 (receptora cholinergicznego muskarynowego typu 2), MAOA (monoaminooksydazy A) i GRM3 (metabotropowego receptora glutaminergicznego). Wykazano również związki między ogólnymi zdolnościami poznawczymi a genami wpływającymi na rozwój lub prawidłowe funkcjonowanie mózgu, do których należą gen NCSTN (nikastryny), PRNP (białka prionowego), DTNBP1 (dysbindyny), UBE3A (ligazy ubikwityny) i FMR1 (fragile $X$ mental retardation 1). Za geny wpływające na procesy poznawcze uważa się także kluczowy $\mathrm{w}$ procesie egzocytozy $\mathrm{w}$ synapsach gen syntaksyny STX1A (syntaxin 1A)oraz geny skorelowane $\mathrm{z}$ występowaniem zespołu Williamsa: LIMK1 (kinazy LIM), CLIP2 (CAP-GLY domain containing linker protein 2), GTF2I (general transcription factor IIi) i GTF2IRD1 (GTF2I repeat domain-containing 1). Geny LIMK1 oraz CLIP2 kodują białka ważne dla właściwej struktury i funkcji neuronów a produkty genów GTF2I i GTF2IRD1 to czynniki transkrypcyjne (regulujące procesy transkrypcji). Obserwowano także korelację między zaburzeniami poznawczymi i mutacjami w genach zaangażowanych w podstawowe procesy metaboliczne w organizmie, takich jak gen $P A H$ (hydroksylazy fenyloalaniny) i HPRT1 (fosforybosylotransferazy hypoksantyny) oraz niezbędnego $\mathrm{w}$ rozwoju embrionalnym genu MECP2 (produkt wpływa na procesy metylacji genów), a nawet niektórymi genami wpływającymi na procesy odpowiedzi immunologicznej, np. CTSD (katepsyny D) i IGFR2 (receptora insulinopodobnego czynnika wzrostu typu 2; oficjalny symbol FCGR2A) (Plomin, DeFries, McClearn, \& McGuffin 2001, 157-166, 202-224; Oniszczenko \& Dragan 2008, 57-63; Gao et al. 2010; Schubert 2009; Tassabehji 2003). Najnowsze badania wskazują też na związek między genami NPTN (neuroplastin) oraz KCNMA1 (potassium channel, calcium activated large conductance subfamily M alpha, member 1), NRXN1 (neurexin 1), POU3F2 (POU class 3 homeobox 2) i SCRT (scratch family zinc finger 1) oraz zdolnościami poznawczymi (Desrivières et al. 2014; Rietveld et al. 2014). Geny POU3F2 i 
SCRT kodują regulatory transkrypcji ważne dla różnicowania komórek nerwowych, natomiast gen KCNMA1 kanał potasowy niezbędny dla zachowania pobudliwości neuronów. NRXN1 to gen neureksyny, funkcjonującej w układzie nerwowym jako białkao adhezyjne, umożliwiające przyleganie komórek do siebie, natomiast gen NPTN koduje białko transmembranowe zaangażowane w oddziaływania między komórkami. Niestety, rozszerzenie zakresu prowadzonych analiz polimorfizmu w populacji ludzkiej podało w wątpliwość wiarygodność wcześniej ustalonych związków - m.in. w odniesieniu do genów DTNBP1, CTSD, DRD2, CHRM2, SSADH, COMT, BDNF i APOE (Chabris et al. 2012).

\section{Podsumowanie}

Niezwykle szybki rozwój technik badawczych doprowadził w ostatnich latach do znacznego poszerzenia wiedzy o biologii naszego gatunku. Po raz pierwszy możemy też podejmować próby wyjaśnienia neurobiologicznego podłoża cech psychicznych oraz ich związków z genetyką. Musimy jednak pamiętać o ograniczeniach stosowanych przez nas metod (np. neuroobrazowania) oraz o statystycznym charakterze obserwowanych związków między polimorfizmem genetycznym a cechami psychicznymi. Intensywne badania miały także nieprzewidziane skutki, ujawniając istnienie wcześniej nieznanych mechanizmów molekularnych, odgrywających jednak ogromną rolę $w$ relacjach między genotypem a fenotypem. Jeszcze niedawno uważaliśmy zjawiska epigentyczne za marginalne, a większość naszego materiału genetycznego określaliśmy mianem „śmieciowego DNA”, przekonani, że nie odgrywa on $w$ naszym organizmie żadnej ważnej roli. Obecnie zachowujemy znacznie wiekszą ostrożność przy formułowaniu wniosków, świadomi ogromnej złożoności procesów i zróżnicowania czynników zaangażowanych w tworzenie cech fenotypowych, a szczególnie cech psychicznych każdej ludzkiej jednostki. Coraz częściej mówimy o analizie złożonych systemów, takich jak konektom i interferom, co wymaga nowych podejść badawczych. Coraz obficiej też sięgamy do innych systemów komórkowych w mózgu - obok sieci neuronów badamy sieci komórek towarzyszących, takich jak astrocyty (Nimmerjahn \& Bergles 2015,) oraz interakcje między tymi systemami. Co więcej, nie potrafimy przewidzieć, które geny mogą odegrać decydującą rolę $\mathrm{w}$ udoskonalaniu naszego gatunku, prowadząc do rzeczywistych zmian jakościowych. Dobitnym przykładem są znane nam geny związane z ludzkimi zdolnościami językowymi, występujące także u ptaków śpiewających i prawdopodobnie uaktywnione przez przypadkową mutację w linii filogenetycznej człowieka (Matsunaga \& Okanoya 2009; Petkov \& Jarvis 2012). Skuteczne ulepszanie np. zdolności poznawczych wymaga zatem dogłębnego zrozumienia wspominanych tu związków i zależności, musi też uwzględniać różnice indywidualne, gdyż reakcje na te 
same czynniki mogą być skrajnie różne. Takie ulepszanie ma więc na razie jedynie charakter hipotetyczny i nie wiadomo kiedy (i czy w ogóle) będziemy w stanie wystarczająco precyzyjnie przewidzieć skutki takich działań w każdym konkretnym przypadku.

\section{Literatura}

Agren, T., Furmark, T., Eriksson, E., \& Fredrikson, M. 2012. „Human Fear Reconsolidation and Allelic Differences In Serotonergic and Dopaminergic Genes." Transl Psychiatry 2(76).

Andersson, E., Rück, C., Lavebratt, C., Hedman, E., Schalling, M., Lindefors, N., Eriksson, E., Carlbring, P., Andersson, G., \& Furmark, T. 2013. „Genetic Polymorphisms in Monoamine Systems and Outcome of Cognitive Behavior Therapy for Social Anxiety Disorder." PLoS One 8(11).

Aksoy-Aksel, A., Zampa, F., Schratt, \& G. 2014. „MicroRNAs and Synaptic Plasticity-A Mutual Relationship." Philos Trans R Soc Lond B Biol Sci: 369(1652).

Anthoni, H., Zucchelli, M., Matsson, H., Müller-Myhsok, B., Fransson, I., Schumacher, J., Massinen, S., Onkamo, P., Warnke, A., Griesemann, H., Hoffmann, P., Nopola-Hemmi, J., Lyytinen, H., Schulte-Körne, G., Kere, J., Nöthen, M. M., \& Peyrard-Janvid, M. 2007. "A Locus On 2p12 Containing the Co-Regulated MRPL19 and C2ORF3 Genes is Associated to Dyslexia." Hum Molec Genet. 16(6): 667-677

Antony, J. W., Gobel, E. W., O’Hare, J. K., Reber, P. J., Paller, K. A. 2012. "Cued Memory Reactivation During Sleep Influences Skill Learning." Nature Neurosci. 15(8): 1114-1116

Antropologia, 1985. Red. naukowa R. Malinowski \& J. Strzałko. PWN: WarszawaPoznań.

Argue, D., Donlon, D., Groves, C., \& Wright, R. 2006. "Homo Floresiensis: Microcephalic, Pygmoid, Australopithecus, or Homo?." Journal of Hum Evol 51(4): 360-374

Arodź, T. \& Płonka, P. M. 2012. "Effects of Point Mutations On Protein Structure Are Nonexponentially Distributed." Proteins 80(7): 1780-90; doi: $10.1002 /$ prot. 24073

Arodź, T. \& Płonka, P. M. 2013. "Sequence and Structure Space Model of Protein Divergence Driven By Point Mutations." Journal Theor Biol. 330:1-8; doi: 10.1016/j.jtbi.2013.03.015

Arzi, A., Shedlesky, L., Ben-Shaul, M., Nasser, K., Oksenberg, A., Hairston, I. S., \& Sobel, N. 2012. "Humans Can Learn New Information During Sleep." Nature Neurosci. 15(10): 1460-1465 
Baab, K. L., McNulty, K. P., Harvati, K. 2013. "Homo Floresiensis Contextualized: A Geometric Morphometric Comparative Analysis of Fossil and Pathological Human Samples." PLoS One 8(7): e69119; doi: 10.1371/journal.pone.0069119

Berger, L. R., Churchill, S. E., De Klerk, B., \& Quinn, R. L. 2008. "Small-Bodied Humans from Palau, Micronesia." PLoS ONE 3(3): e1780; Erratum w: PLOS ONE 2008: 3(3); doi:10.1371/annotation/0b1a375a-ea43-4586$824 \mathrm{f}-05 \mathrm{bc} 5 \mathrm{~b} 359 \mathrm{~d} 63$

Bodnar, J. W. 1997. "Programming the Drosophila Embryo." J Theor Biol. 188: 391-445

Bodnar, J. W., Bradley, M. K. 2001. "Programming the Drosophila Embryo 2." Cell Biochem Biophys. 34:153-190

Bos, M. G., Beckers, T., \& Kindt, M. 2014. "Noradrenergic Blockade of Memory Reconsolidation: A Failure to Rrduce Conditioned Fear Responding." Front Behav Neurosci. 8: 412; doi: 10.3389/fnbeh.2014.00412

Bostrom, N. 2013. "Why I Want To Be a Posthuman When I Grow Up". W M. More, N. Vita-More (eds.), The Transhumanist Reader. Classical and Contemporary Essays on the Science, Technology, and Philosophy of the Human Future. NY: Wiley-Blackwell.

Brown, P., Sutkina, T., Morwood, M. J., Soejono, R. P., Jatmiko et al. 2004. "A New Small-Bodied Hominin from the Late Pleistocene of Flores, Indonesia." Nature 431(7012): 1055-1061.

Chabris, C.F., Hebert, B.M., Benjamin, D. J., Beauchamp, J., Cesarini, D., van der Loos, M., Johannesson, M., Magnusson, P. K., Lichtenstein. P., Atwood, C. S., Freese, J., Hauser, T. S., Hauser, R. M., Christakis. N., \& Laibson, D. 2012. "Most Reported Genetic Associations with General Intelligence Are Probably False Positives." Psychol Sci. 23(11): 1314-23; doi: 10.1177/0956797611435528

Chamary, J. V., Parmley, J. R., \& Hurst, L. D. 2006. "Hearing Silence: Non-Neutral Evolution at Synonymous Sites In Mammals." Nat Rev Genet 7: 98-108.

Człowiek i psychologia, 2004. red. naukowa J. Rybakiewicz, wyd. I. PPU PARK: Bielsko-Biała.

Dana, A. \& Tuller, T. 2014. "Mean of the Typical Decoding Rates: A New Translation Efficiency Index Based on the Analysis of Ribosome Profiling Data." G3 (Bethesda) 5(1): 73-80; doi: 10.1534/g3.114.015099.

Dąbrowski, K. 1985. “Co to jest zdrowie psychiczne?” W idem (red. naukowa), Zdrowie psychiczne. Warszawa: PWN.

de Bitencourt, R. M., Pamplona, F. A., Takahashi, R. N. 2013. "A Current Overview of Cannabinoids and Glucocorticoids in Facilitating Extinction of Aversive Memories: Potential Extinction Enhancers." Neuropharmacology 64: 389-95; doi: 10.1016/j.neuropharm.2012.05.039 
DeGrazia, D. 2005. "Enhancement Technologies and Human Identity." Journal Med Philos. 30(3): 261-83.

Desrivières, S., Lourdusamy, A., Tao, C., Toro, R., Jia, T., Loth, E., Medina, L. M., Kepa, A., Fernandes, A., Ruggeri, B., Carvalho, F. M., Cocks, G., Banaschewski, T., Barker, G. J., Bokde, A. L., Büchel, C., Conrod, P. J., Flor, H., Heinz, A., Gallinat, J., Garavan, H., Gowland, P., Brühl, R., Lawrence, C., Mann, K., Martinot, M. L., Nees, F., Lathrop, M., Poline, J. B., Rietschel, M., Thompson, P., Fauth-Bühler, M., Smolka, M. N., Pausova, Z., Paus, T., Feng, J., \& Schumann, G. 2014. "Single Nucleotide Polymorphism in the Neuroplastin Locus Associates with Cortical Thickness and Intellectual Ability in Adolescents." Molecular Psychiatry, Feb 11; doi: 10.1038/mp.2013.197

Devanna, P., Middelbeek, J., Vernes, S. C. 2014. "FOXP2 Drives Neuronal Differentiation By Interacting with Retinoic Acid Signaling Pathways." Front Cell Neurosci. 8: 305; doi: 10.3389/fncel.2014.00305

Diekelmann, S. \& Born, J. 2010. "The Memory Function of Sleep." Nature Reviews Neurosci. 11(2): 114-126.

Eckhardt, R. B., Henneberg, M., Weller, A. S., \& Hsü, K. J. 2014. "Rare Events in Earth History Include the LB1 Human Skeleton from Flores, Indonesia, As a Developmental Singularity, Not a Unique Taxon." Proc Natl Acad Sci USA 111(33): 11961-6; doi: 10.1073/pnas.1407385111

Encyklopedia Biologiczna 1998. t. II, III, IV, VII. Agencja PublicystycznoWydawnicza Opres: Kraków.

Erler, A. 2011. "Does Memory Modification Threaten Our Authenticity?" Neuroethics 4(3): 235-249.

File, S. E., Fluck, E., \& Fernandes, C. 1999. "Beneficial Effects of Glycine (Bioglycin) on Memory and Attention in Young and Middle-Aged Adults." Journal of Clin Psychopharmacol 19: 506-512.

Fisher, S. E. 2006. "Tangled Webs: Tracing the Connections Between Genes and Cognition." Cognition 101(2): 270-97.

Fisher, S. E. \& Scharff, C. 2009. "FOXP2 as a Molecular Window Into Speech and Language." Trends Genet. 25: 166-177.

Fisher, S. E., Vargha-Khadem, F., Watkins, K. E., Monaco, A. P., \& Pembrey, M. E. 1998. "Localisation of a Gene Implicated in a Severe Speech and Language Disorder." Nature Genet. 18(2): 168-170.

Flynn, J. R. 1984. "The Mean IQ of Americans: Massive Gains 1932 to 1978." Psychol Bull. 95: 29-51.

Forlini, C., Hall, W., Maxwell, B., Outram, S. M., Reiner, P. B., Repantis, D., Schermer, M., \& Racine, E. 2013. "Navigating the Rnhancement Landscape. Ethical Issues in Research on Cognitive Enhancers for Healthy Individuals." EMBO Rep. 14(2): 123-8; doi: 10.1038/embor.2012.225 
Fraga, M. F., Ballesta, E., Paz, M. F., Ropero, S., Setien, F., Ballestar, M. L., HeineSuñer, D., Cigudosa, J. C., Urioste, M., Benitez, J., Boix-Chornet, M., Sanchez-Aguilera, A., Ling, C., Carlsson, E., Poulsen, P., Vaag, A., Stephan, Z., Spector, T. D., Wu, Y. Z., Plass, C., \& Esteller, M. 2005. "Epigenetic Differences Arise During the Lifetime of Monozygotic Twins". Proc Natl Acad Sci USA 102(30): 10604-10609.

Fu, L, Shi, Z., Luo, G., Tu, W., Wang, X., Fang, Z., \& Li, X. 2014. "Multiple MicroRNAs Regulate Human FOXP2 Gene Expression by Targeting Sequences in Its 3' Untranslated Region." Mol Brain 7: 71: doi: 10.1186/s13041-014-0071-0

Fung, K. L. \& Gottesman, M. M. 2009. "A Synonymous Polymorphism in a Common MDR1 (ABCB1) haplotype shapes protein function, Biochim Biophys Acta 1794: 860-871.

Garner, A. R., Rowland, D. C., Hwang, S. Y., Baumgaertel, K., Roth, B. L., Kentros, C., \& Mayford, M. 2012. "Generation of a Synthetic Memory Trace." Science 335(6075): 1513-1516.

Gerstein, M. B., Bruce, C., Rozowsky, J. S., Zheng, D., Du, J., Korbel, J. O., Emanuelsson, O., Zhang, Z. D., Weissman, S., \& Snyder, M. 2007. "What Is a Gene, Post-ENCODE? History and Updated Definition." Genome Res. 17(6): 669-81.

Gao, M. C., Bellugi, U., Dai, L., Mills, D. L., Sobel, E. M., Lange, K., \& Korenberg, J. R., 2010. "Intelligence in Williams Syndrome Is Related to STX1A, Which Encodes a Component of the Presynaptic SNARE Complex." PLoS ONE 5(4): e10292; doi: 10.1371/journal.pone.0010292

Gläscher, J., Rudrauf, D., Colom, R., Paul, L. K., Tranel, D., Damasio, H., \& Adolphs. R. 2010. "Distributed Neural System for General Intelligence Revealed By Lesion Mapping," Proc Natl Acad Sci USA 107(10): 4705-4709.

Greiffenstein, M. F. 2011. "Secular IQ Increases By Epigenesis? The Hypothesis of Cognitive Genotype Pptimization." Psychol Rep. 109(2): 353-66.

Greń, J. 1987. Statystyka matematyczna. PWN: Warszawa.

Griffiths, B. B. \& Hunter, R. G. 2014. "Neuroepigenetics of Stress." Neuroscience 275: 420-435.

Guilford, J. P. 1978. Natura inteligencji człowieka. Tłum. B. Czarniawska, W. Kozłowski i J. Radzicki. PWN: Warszawa.

Hamani C., McAndrews, M. P., Cohn, M., Oh, M., Zumsteg, D., Shapiro, C. M., \& Lozano, A. M. 2008. "Memory Enhancement Induced By Hypothalamic/Fornix Deep Brain Stimulation." Ann Neurol. 63(1): 119123.

Han, J. H., Kushner, S. A., Yiu, A. P., Hsiang, H. L., Buch, T., Waisman, A., Bontempi, B., Neve, R. L., Frankland, P. W., \& Josselyn, S. A. 2009. "Selective Erasure of a Fear Memory." Science 323(5920): 1492-6; doi: 10.1126/science.1164139 
Harris, E. E. \& Meyer, D. 2006. "The Molecular Signature of Selection Underlying Human Adaptations." Am J Phys Anthropol. Suppl 43: 89-130.

He, Y. \& Casaccia-Bonnefil, P. 2008. "The Yin and Yang of YY1 in the Nervous System." Journal Neurochem. 106(4): 1493-502; doi: 10.1111/j.14714159.2008.05486.x

Henneberg, M., Eckhardt, R. B., Chavanaves, S., \& Hsü, K. J. 2014. "Evolved Developmental Homeostasis Disturbed in LB1 from Flores, Indonesia, Denotes Down Syndrome and Not Diagnostic Traits of the Invalid Species Homo Floresiensis." Proc Natl Acad Sci USA 111(33): 11967-72; doi: $10.1073 /$ pnas.1407382111

Hershkovitz, I., Kornreich, L., \& Laron, Z. 2007. "Comparative Skeletal Features Between Homo Floresiensis and Patients with Primary Growth Hormone Insensitivity (Laron Syndrome)." Am J Phys Anthropol. 134(2): 198-208.

Hu, H. Y., He, L., Fominykh, K., Yan, Z, Guo, S., Zhang, X., Taylor, M. S., Tang, L., Li, J., Liu, J., Wang, W., Yu, H., \& Khaitovich, P. 2012. "Evolution of the Human-Specific microRNA miR-941." Nat Commun. 3: 1145; doi: 10.1038/ncomms2146

Imamura, T., Uesaka, M., \& Nakashima, K. 2014. "Epigenetic Setting and Reprogramming for Neural Cell Fate Determination and differentiation." Philos Trans $R$ Soc Lond B Biol Sci. 369(1659) 20130511; doi: 10.1098/rstb.2013.0511

Jacob, T., Indriati, E., Soejono, R. P., Hsu, K., Frayer, D. W., Eckhardt, R. B., Kuperavage, A. J., Thorne, A., \& Henneberg, M. 2006. "Pygmoid Australomelanesian Homo Sapiens Skeletal Remains from Liang Bua, Flores: Population Affinities and Pathological Abnormalities." Proc Natl Acad Sci USA 103(36): 13421-13426

Jarome, T. J., Thomas, J. S., \& Lubin, F. D. 2014. "The Epigenetic Basis of Memory Formation and Storage." Prog Mol Biol Transl Sci. 28: 1-27; doi: 10.1016/B978-0-12-800977-2.00001-2

Ji, S. 1999. "The Linguistics of DNA: Words, Sentences, Grammar, Phonetics, and Semantics." Ann NY Acad Sci. 870: 411-417.

Jura, Cz. 1998. „Cecha wrodzona”. Encyklopedia Biologiczna, t. II. Kraków: Agencja Publicystyczno-Wydawnicza Opres.

Jura, Cz. \& Krzanowska, H. 1998. „Cecha”. Encyklopedia Biologiczna, t. II. Kraków: Agencja Publicystyczno-Wydawnicza Opres.

Kaczanowski, K. 1998a. „Cechy specyficznie ludzkie”. Encyklopedia Biologiczna, t. II. Kraków: Agencja Publicystyczno-Wydawnicza Opres.

Kaczanowski, K. 1998b. „Norma biologiczna”. Encyklopedia Biologiczna, t. II. Kraków: Agencja Publicystyczno-Wydawnicza Opres.

Kindt, M., Soeter, M., \& Sevenster, D. 2014. "Disrupting Reconsolidation of Fear Memory in Humans by a Noradrenergic $\beta$-Blocker." $J$ Vis Exp. Dec 18(94); doi: 10.3791/52151 
Kingsley, D. M. 2009. "From Atoms to Traits." Sci Am 300(1): 52-59.

Krzanowska, H. 1998a. „Fenotyp”. Encyklopedia Biologiczna, t. III. Kraków: Agencja Publicystyczno-Wydawnicza Opres.

Krzanowska, H. 1998b. „Genotyp”. Encyklopedia Biologiczna, t. III, j.w.

Krzanowska, H. 1998c. „Cecha ilościowa”. Encyklopedia Biologiczna, t. III, j.w.

Krzanowska, H. 1998d. „Cecha jakościowa”. Encyklopedia Biologiczna, t. III, j.w.

Krzanowska, H. 1998e. „Cecha metryczna”. Encyklopedia Biologiczna, t. III, j.w.

Kubo, D., Kono, R. T., \& Kaifu, Y. 2013. "Brain Size of Homo Floresiensis and Its Evolutionary Implications." Proc Biol Sci., 280(1760): 20130338; doi: 10.1098/rspb.2013.0338

Kudla, G., Murray, A. W., Tollervey, D., \& Plotkin, J. B. 2009. "Coding-Sequence Determinants of Gene Expression in Escherichia coli." Science 324(5924): 255-258; doi: 10.1126/science.1170160

Kumar, R. 2008. "Approved and Investigational Uses of Modafinil: An Evidence-Based Review." Drugs 68(13): 1803-1839.

Kunicki-Goldfinger, W. J. H. 1978. Podstawy biologii. Od bakterii do człowieka. PWN: Warszawa.

Kuriyama, K., Honma M., Yoshiike T., \& Kim, Y. 2013. "Valproic Acid But Bot DCycloserine Facilitates Sleep-Dependent Offline Learning of Extinction and Habituation of Conditioned Fear In Humans." Neuropharmacology 64: 424-431.

Laxton, A. W., Tang-Wai, D. F., McAndrews, M. P., Zumsteg, D., Wennberg, R., Keren, R., \& Lozano, A. M. 2010. "A Phase I Trial of Deep Brain Stimulation of Memory Circuits In Alzheimer's Disease." Ann Neurol. 68(4): 521-534.

LePort, A. K., Mattfeld, A.T., Dickinson-Anson, H., Fallon, J. H., Stark, C. E., Kruggel, F., Cahill, L., \& McGaugh, J. L. 2012. "Behavioral and Neuroanatomical Investigation of Highly Superior Autobiographical Memory (HSAM)." Neurobiol Learn Mem. 98(1): 78-92; doi: 10.1016/j.nlm.2012.05.002

Levy, Y. \& Ebstein, R. P. 2009. "Research Review: Crossing Syndrome Boundaries in the Search for Brain Endophenotypes," J Child Psychol Psychiatry 50(6): 657-668; doi: 10.1111/j.1469-7610.2008.01986.x

Liao, S. M. \& Sandberg, A. 2008. "The Normativity of Memory Modification." Neuroethics 1(2): 85-99.

Liegeois, F., Baldeweg, T., Connelly, A., Gadian, D. G., Mishkin, M., \& VarghaKhadem, F. 2003. "Language fMRI Abnormalities Associated with FOXP2 Gene Mutation." Nature Neurosci. 6(11): 1230-1237.

Marcus, G. F. \& Fisher, S. E. 2003. "FOXP2 in Focus: What Can Genes Tell Us about speech and language?". Trends Cogn Sci. 7(6): 257-262.

Marshall, L., Helgadóttir, H., Mölle, M., \& Born, J. 2006. "Boosting Slow Pscillations During Sleep Potentiates Memory." Nature 444(7119): 610613. 
Matsunaga, E. \& Okanoya, K. 2009. "Evolution and Diversity in Avian Vocal System: An Evo-Devo Model from the Morphological and Behavioral Üerspectives." Dev Growth Differ 51(3): 355-67; doi: 10.1111/j.1440169X.2009.01091.x

Mohamed, A. D. \& Sahakian, B. J. 2012. "The Ethics of elective Psychopharmacology." Int J Neuropsychopharmacol. 15: 559-571.

Mukamel, Z., Konopka, G., Wexler, E., Osborn, G. E., Dong, H., Bergman, M. Y., Levitt, P., \& Geschwind, D. H. 2011. "Regulation of MET by FOXP2, Genes Implicated in Higher Cognitive Dysfunction and Autism Risk." J Neurosci. 31(32): 11437-11442; doi: 10.1523/JNEUROSCI.018111.2011

Müller, U., Rowe, J. B., Rittman, T., Lewis, C., Robbins, T. W., \& Sahakian, B. J. 2013. "Effects of Modafinil On Non-Verbal Cognition, Task Enjoyment and Creative Thinking in Healthy Volunteers." Neuropharmacology 64: 490-495; doi: 10.1016/j.neuropharm.2012.07.009

Newbury, D. F., Winchester, L., Addis, L., Paracchini, S., Buckingham, L. L., Clark, A., Cohen, W., Cowie, H., Dworzynski, K., Everitt, A., Goodyer, I. M., Hennessy, E., Kindley, A. D., Miller, L. L., Nasir, J., O'Hare, A., Shaw, D., Simkin, Z., Simonoff, E., Slonims, V., Watson, J., Ragoussis, J., Fisher, S. E., Seckl, J. R., Helms, P. J., Bolton, P. F., Pickles, A., Conti-Ramsden, G., Baird, G., Bishop, D. V., \& Monaco, A. P. 2009. "CMIP and ATP2C2 Modulate Phonological ShortTerm Memory in Language Impairment." Am J Hum Genet. 85(2): 264-272.

Nicolas, M. \& Hassan, B. A. 2014. "Amyloid Precursor Protein and Aeural Development." Development 141(13): 2543-2548; doi: 10.1242/dev.108712

Nimmerjahn, A. \& Bergles, D. E. 2015. "Large-Scale Recording of Astrocyte Activity." Curr Opin Neurobiol. 32C: 95-106; doi: 10.1016/j.conb.2015.01.015

Oniszczenko, W. \& Dragan, W. Ł. 2008. Genetyka zachowania w psychologii $i$ psychiatrii. Wydawnictwo Naukowe Scholar: Warszawa.

Oudiette, D. \& Paller K. A. 2013. Upgrading the Sleeping Brain with targeted Memory Reactivation." Trends Cogn Sci. 17(3): 142-9; doi: 10.1016/j.tics.2013.01.006

Paracchini, S. 2011. "Dissection of Genetic Associations with Language-Related Traits in Population-Based Cohorts." J. Neurodev Disord. 3: 365-373.

Patihis, L., Frenda, S. J., LePort, A. K., Petersen, N., Nichols, R. M, Stark, C. E., McGaugh, J. L., \& Loftus, E. F. 2013. "False Memories in Highly Superior Autobiographical Memory Individuals." Proc Natl Acad Sci USA 110(52): 20947-52; doi: 10.1073/pnas.1314373110

Petkov, C. I. \& Jarvis, E. D. 2012. "Birds, Primates, and Spoken Language Origins: Nehavioral Phenotypes and Neurobiological Substrates." Front Evol Neurosci. 4: 12; doi: 10.3389/fnevo.2012.00012 
Pietschnig, J., Voracek M., \& Formann, A. K. 2010. "Pervasiveness of the IQ Rise: A cross-temporal Meta-analysis." PLoS One 5(12): e14406; doi: 10.1371/journal.pone.0014406

Plomin, R., DeFries, J. C., McClearn, G. E., \& McGuffin, P. 2001. Genetyka zachowania. Tłum. E. Czerniawska i K. Duniec. PWN: Warszawa.

Tomaszewski, T. (red. naukowa) 1979. Psychologia, wyd. V. PWN: Warszawa.

Qureshi, I. A., \& Mehler, M. F. 2014. "An Evolving View of Epigenetic Complexity in the Brain." Philos Trans R Soc Lond B Biol Sci. 369(1652); pii: 20130506. doi: 10.1098/rstb.2013.0506

Rabinak, C. A., Angstadt, M., Sripada, C. S., Abelson, J. L., Liberzon, I., Milad, M. R., \& Phan, K. L. 2013. "Cannabinoid Facilitation of Fear Extinction Memory Recall in Humans." Neuropharmacology 64: 396-402.

Ramirez, S., Liu, X., Lin, P. A., Suh, J., Pignatelli, M., Redondo, R. L., \& Tonegawa, S. 2013. "Creating a False Memory in the Hippocampus." Science 341(6144): 387-391.

Rasch, B., Büchel, C., Gais, S., \& Born, J. 2007. "Odor Cues During Slow-Wave Sleep Prompt Declarative Memory Consolidation." Science 315(5817): 1426-1429.

Repantis, D., Laisney, O., \& Heuser, I. 2010a. "Acetylcholinesterase Inhibitors and Memantine for Neuroenhancement in Healthy Individuals: A Systematic Review." Pharmacol Res. 61(6): 473-81; doi: 10.1016/j.phrs.2010.02.009

Repantis, D., Schlattmann, P., Laisney, O., Heuser, I. 2010b. "Modafinil and Methylphenidate for Neuroenhancement in Healthy Individuals: A Systematic Review." Pharmacol Res. 62(3): 187-206; doi: 10.1016/j.phrs.2010.04.002

Rietveld, C. A., Esko, T., Davies, G., Pers, T. H., Turley, P., Benyamin, B., Chabris, CF, Emilsson, V-, Johnson, A. D., Lee, J. J., de Leeuw, C., Marioni, R. E., Medland, S. E., Miller, M. B., Rostapshova, O., van der Lee, S. J., Vinkhuyzen, A. A., Amin, N., Conley, D., Derringer, J., van Duijn, C. M., Fehrmann, R., Franke L, Glaeser E. L., Hansell, N. K., Hayward C, Iacono, W. G., Ibrahim-Verbaas, C., Jaddoe, V., Karjalainen, J., Laibson, D., Lichtenstein, P., Liewald, D. C., Magnusson, P. K., Martin, N. G., McGue, M., McMahon, G., Pedersen, N. L., Pinker, S., Porteous, D. J., Posthuma, D., Rivadeneira, F., Smith, B. H., Starr, J. M., Tiemeier, H., Timpson, N. J., Trzaskowski, M., Uitterlinden, A. G., Verhulst, F. C., Ward, M. E., Wright, M. J., Davey Smith, G., Deary, I. J., Johannesson, M., Plomin, R., Visscher, P. M., Benjamin, D. J., Cesarini, D., \& Koellinger, P. D. 2014. "Common Genetic Variants Associated with Cognitive Performance Identified Using the Proxy-Phenotype Method." Proc Natl Acad Sci USA.111(38): 13790-13794; doi: 10.1073/pnas.1404623111

Roberts, T. C., Morris, K. V., \& Wood, M. J. 2014. "The Role of Long Non-Coding RNAs in Neurodevelopment, Brain Function and Neurological disease." 
Philos Trans R Soc Lond B Biol Sci. 369(1652); pii: 20130507. doi: 10.1098/rstb.2013.0507

Rodríguez, M. L. C., Campos, J., Forcato, C., Leiguarda, R., Maldonado, H., Molina, V. A., \& Pedreira, M. E. 2013. "Enhancing a Declarative Memory in Humans: The Effect of Clonazepam on Reconsolidation." Neuropharmacology 64: 432-442.

Rolls, A., Makam, M., Kroeger, D., Colas, D., de Lecea, L., \& Heller, H.C. 2013. "Sleep to Forget: Interference of Fear Memories During Sleep." Mol Psychiatry 18: 1166-1170.

Rudoy, J. D., Voss, J. L., Westerberg, C. E., \& Paller, K. A. 2009. "Strengthening Individual Memories By Reactivating Them During Sleep." Science. 326(5956): 1079.

Rutter, M., Moffitt, T. E., \& Caspi, A. 2006. "Gene-Environment Interplay and Psychopathology: Multiple Varieties But Real Effects." J Child Psychol Psychiatry 47(3-4): 226-261.

Scerri, T. S., Morris, A. P., Buckingham, L. L., Newbury, D. F., Miller, L. L., Monaco, A. P., Bishop, D. V., \& Paracchini, S. 2011. "DCDC2, KIAA0319 and CMIP Are Associated with Reading-Related Traits." Biol Psychiatry 70(3): 237-245.

Schubert, C. 2009. "The Genomic Basis of the Williams-Beuren Syndrome." Cell Mol Life Sci. 66(7): 1178-1197.

Shen, E., Shulha, H., Weng, Z., \& Akbarian S. 2014. "Regulation of histone H3K4 Methylation in Brain Development and Disease." Philos Trans $R$ Soc Lond B Biol Sci. 369(1652). pii: 20130514; doi: 10.1098/rstb.2013.0514

Shin, J., Ming, G. L., Song, H. 2014. "DNA Modifications In the Mammalian Brain." Philos Trans R Soc Lond B Biol Sci. 369(1652); pii: 20130512; doi: 10.1098/rstb.2013.0512

Shook, J. R., Galvagni, L., \& Giordano, J. 2014. "Cognitive Enhancement Kept Within Contexts: Neuroethics and Informed Public Policy." Front Syst Neurosci. 8: 228. doi: 10.3389/fnsys.2014.00228

Spiteri, E., Konopka, G., Coppola, G., Bomar, J., Oldham, M., Ou, J., Vernes, S. C., Fisher, S. E., Ren, B., \& Geschwind, D. H. 2007. "Identification of the Transcriptional Targets of FOXP2, a Gene Linked to Speech and Language, in Developing Human Brain." Am J Hum Genet. 81(6): 1144-1157.

Stetler, R. A., Gan, Y., Zhang, W., Liou, A. K., Gao, Y., Cao, G., \& Chen, J. 2010. "Heat Shock Proteins: Cellular and Molecular Mechanisms In the Central Nervous System." Prog Neurobiol. 92(2): 184-211; doi: 10.1016/j.pneurobio.2010.05.002

Strachan, T. \& Read, A. P. 1999. Human Molecular Genetics. $2^{\text {nd }}$ edition. BIOS Scientific Publishers Ltd: Oxford 
Styrna, J. W. 1998. „Informacja genetyczna”. Encyklopedia Biologiczna, t. IV. Kraków: Agencja Publicystyczno-Wydawnicza Opres.

Suthana, N., Haneef, Z., Stern, J., Mukamel, R., Behnke, E., Knowlton, B., \& Fried, I. 2012. "Memory Enhancement and Deep-Brain Stimulation of the Entorhinal Area." N Engl J Med. 366(6): 502-510.

Szyf, M., Weaver, I., \& Meaney, M. 2007. "Maternal Care, the Epigenome and Phenotypic Differences in Behavior." Reprod Toxicol. 24(1): 9-19.

Tassabehji, M. 2003. "Williams-Beuren Syndrome: A Challenge for GenotypePhenotype Correlations." Hum Molec Genet. 12(Spec No 2), R229-R237; doi: $10.1093 / \mathrm{hmg} / \mathrm{ddg} 299$

Trahan, L. H., Stuebing, K. K., Fletcher, J. M., \& Hiscock, M. 2014. "The Flynn Effect: A Meta-Analysis." Psychol Bull. 140(5): 1332-60; doi: $10.1037 / \mathrm{a} 0037173$

Tsai, Ch.-J., Sauna, Z. E., Kimchi-Sarfaty, Ch., Ambudkar, S. V., Gottesman, M. M. \&, Nussinov, R. 2008. "Synonymous Mutations and Ribosome Stalling Can Lead to Altered Folding Pathways and Distinct Minima." J Mol Biol. 383: 281-291.

Vernes, S. C., Newbury, D. F., Abrahams, B. S., Winchester, L., Nicod, J., Groszer, M., Alarcon, M., Oliver, P. L., Davies, K. E., Geschwind, D. H., Monaco, A. P., \& Fisher, S. E. 2008. "A Functional Genetic Link Between Distinct Developmental Language Disorders." N Engl J Med. 359(22): 23372345.

Wade, L., Forlini, C., \& Racine, E. 2014. "Generating Genius: How an Alzheimer's Drug Became Considered a 'Cognitive Enhancer' for Healthy Individuals." BMC Med Ethics 15: 37; doi: 10.1186/1472-6939-15-37

Weaver, I. C., Hellstrom, I. C., Brown, S. E., Andrews, S. D., Dymov, S., Diorio, J., Zhang, T. Y., Szyf, M., \& Meaney, M. J. 2014. "The Methylated-DNA Binding Protein MBD2 Enhances NGFI-A (egr-1)-Mediated Transcriptional Activation of the Glucocorticoid Receptor." Philos Trans $R$ Soc Lond B Biol Sci. 369(1652); pii: 20130513; doi: 10.1098/rstb.2013.0513

Wood, N. E., Rosasco, M. L., Suris, A. M., Spring, J. D., Marin, M. F., Lasko, N. B., Goetz, J. M., Fischer, A. M., Orr, S. P., \& Pitman, R. K. 2015. "Pharmacological Blockade of Memory Reconsolidation in Posttraumatic Stress Disorder: Three Negative Psychophysiological Studies." Psychiatry Res. 225(1-2): 31-9; doi: 10.1016/j.psychres.2014.09.005

Wortman, C. B., Loftus, E. F., \& Marshall, M. E. 1992. Psychology, $4^{\text {th }}$ ed. NY: McGraw-Hill, Inc.

Yoshimoto, R., Okawa, K., Yoshida, M., Ohno, M., \& Kataoka, N. 2014. "Identification of a Novel Component C2ORF3 in the Lariat-Intron Complex: Lack of C2ORF3 Interferes with pre-mRNA Splicing Via Intron Turnover Pathway." Genes Cells 19(1): 78-87; doi: 10.1111/gtc.12114 


\title{
Beata Płonka (Kraków)
}

\section{Cechy psychiczne człowieka a idee transhumanizmu}

\section{Man's Mental Features and the Idea of Transhumanizm}

\begin{abstract}
Abstrakt. Celem obecnych rozważań jest spojrzenie na problem udoskonalania człowieka, a zwłaszcza jego cech psychicznych, z perspektywy nauk biologicznych. Wprowadzono więc używane w biologii rozróżnienie genotypu i fenotypu, definicje cech dziedzicznych i nabytych oraz antropologiczną charakterystykę gatunku Homo sapiens przez cechy specyficznie ludzkie. Perspektywa biologiczna (a zwłaszcza ewolucyjna) wskazuje na ogromne trudności w określeniu charakteru i zakresu możliwych ulepszeń naszego gatunku, co związane jest między innymi z problematyką normy biologicznej oraz psychicznej. Wiele uwagi poświęcono złożonym zależnościom między genotypem i fenotypem w żywych organizmach, wyrażającym się m.in. przez polimorfizm oraz efekty epigenetyczne, a także związkom między genami i cechami psychicznymi człowieka. Ostatecznie stwierdzono, że udoskonalanie np. zdolności poznawczych wymaga pełnego zrozumienia tych związków i zależności, uwzględniającego także różnice indywidualne, które wciąż jest jednak dla nas nieosiągalne.
\end{abstract}

Słowa kluczowe: cechy psychiczne, efekty epigenetyczne, fenotyp, genotyp, norma biologiczna

Ethics in Progress (ISSN 2084-9257). Vol. 6 (2015). No. 1, pp. 154-184.

doi: 10.14746/eip.2015.1.12 